RESEARCH ARTICLE

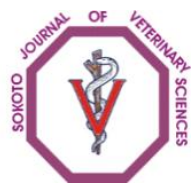

Sokoto Journal of Veterinary Sciences

(P-ISSN 1595-093X/ E-ISSN 2315-6201)

Ejeh et al/Sokoto Journal of Veterinary Sciences (2015) 13(2): 42-48

http://dx.doi.org/10.4314/sokjvs.v13i2.7

\title{
Seasonal prevalence of bovine fasciolosis and its direct economic losses (del) due to liver condemnation at Makurdi abattoirs north central Nigeria
}

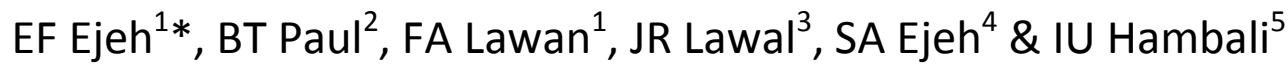

1. Department of Veterinary Microbiology and Parasitology, University of Maiduguri, Nigeria.

2. Veterinary Teaching hospital, University Maiduguri, Nigeria.

3. Department of Veterinary Medicine, University of Maiduguri, Nigeria.

4. Veterinary Teaching hospital, University of Agriculture, Makurdi, Nigeria.

5. Veterinary Public Health and Preventive Medicine, University of Maiduguri, Nigeria

*Correspondence: Tel.: +2348057243878, E-mail: enenchefrancis@yahoo.com

\begin{abstract}
This study was conducted to report the prevalence of bovine fasciolosis and to estimate the direct economic losses (DEL) from condemnation of liver as a result of detection of lesions of fasciolosis in cattle slaughtered in Makurdi abattoirs. Retrospective data were collected from the abattoir records obtained from Ministry of Agriculture and Natural Resources (MANR) Makurdi, from 2008 to 2012. Direct economic losses were calculated based on a pilot study to determine the average price of liver per kilogram (AvP/kg) and using the formula: $\mathrm{DEL}=n \mathrm{w} \times \mathrm{AvP} / \mathrm{kg}$, where $n$ is the number of livers condemned and $W$ is the average liver weight in kg. Between 2008 and 2012, 64,978 cattle were slaughtered at Makurdi abattoirs, out of which 9,478 cattle were infected with Fasciola species. This represents an overall prevalence of $14.56 \%$ (95\%, C.I.: 12.99 $16.85 \%)$. Annual prevalence of bovine fasciolosis was significantly $(P<0.05)$ high in 2010 and decreased from 2011 to 2012. During the late dry season, the prevalence of bovine fasciolosis was significantly high $(P<0.05)$. A total of 4220 liver were condemned during the study period. This amounted to $12660 \mathrm{~kg}$ and valued at \#12,660,000.00 (\$79251.60 USD). The highest prevalence was recorded during the late dry season. However, cattle acquire the infection during the wet season and early dry season. Pathological lesions were much obvious during the late dry season possibly when the animals were most stressed, hence we suggest that control measures should be targeted towards wet and early dry seasons. Bovine fasciolosis is prevalent in cattle slaughtered in Makurdi abattoirs and accounts for huge financial losses.
\end{abstract}

Keywords: Bovine fasciolosis, Economic losses, Makurdi, Prevalence, Season

Received: 07-03- 2015

Accepted: 29-06-2015

\section{Introduction}

Benue state is known as the food basket of Nigeria. It accounts for a significant proportion of agricultural production in Nigeria (Abu et al., 2011) due to its geographical location which provides suitable ecological conditions that favour crop and animal production (Idoga \& Egbe, 2012).

Ruminant production accounts for a high percentage of protein consumption, in addition to generation of revenue for farmers and other stakeholders in livestock trade (Steinfeld, 1997; Blench, 2010). However, livestock productivity in sub-Saharan Africa is constrained by a number of factors prominent among which is diseases, especially, those of parasitic origin (Soulsby, 1982; Blench, 2010).

Bovine fasciolosis is a disease of economic and veterinary importance (Mc Kenna et al., 2002), and has been identified as a major cause of morbidity and mortality in cattle (Soulsby, 1982).

Fasciolosis is caused by members of the subclass: Digenea, genus: Fasciola (Soulsby, 1982). Fasciola gigantica is the cause of fasciolosis (liver fluke) in the tropics while Fasciola hepatica is the frequent cause of fasiolosis in the temperate region of the world. 
Fasciolosis is transmitted by ingestion of metacercaria-infested plant or drinking water containing floating metacercariae (Arjona et al., 1995). Man is infected mainly by eating watercress (Nasturtium officinale) infested with metacercariae. Raw lettuce and cabbage which are common delicacies in northern Nigeria and other contaminated plants that are eaten raw can also be a source of infection, as can water from irrigation ditches or other receptacles. Alfalfa juice has also been implicated in places where people drink this beverage (Pan American Health Organization, 2003).

Fasciolosis caused by $F$. gigantica is responsible for heavy economic losses to farmers due to reduced weight gain, poor carcass quality, reduced milk yield, cost of treatment and control, mortality and condemnation of affected livers at abattoirs in Nigeria (Ekwunife \& Eneanya, 2006; Njoku-Tony, 2011; Okaiyeto et al., 2012; Odigie \& Odigie, 2013; Yahaya \& Tyav, 2014).

The disease is an emerging zoonosis worldwide and the World Health Organisation has estimated that over 2 million people are infected and 180 million are at risk of infection (Khalid et al., 2010).

There have been systematic and coordinated efforts at documenting the prevalence of fasciolosis in livestock in several countries of the world. However, there is paucity of information in recent years on the prevalence of fasciolosis and economic losses from condemnation of livers infected with Fasciola in cattle slaughtered in Makurdi. Therefore, the aim of this study was to investigate the seasonal prevalence and direct economic losses from condemnation of livers due to fasciolosis in cattle slaughtered at abattoirs in Makurdi, Benue state, Nigeria.

\section{Materials and methods}

Study area

Makurdi, the administrative headquarter of Benue state, lies within latitude $7^{\circ} 44^{\prime} \mathrm{N}$ and longitude $8^{0} 54^{\prime} \mathrm{E}$ in north central Nigeria. It is characterised by tropical, dry and wet climate. The dry season lasts for a minimum of six months, beginning from November to April, while the wet season spans from May to October. Mean annual rainfall is about 1,290mm (Gobo, 1988). Makurdi is located in the Benue valley and is drained by the river Benue and its tributaries. Due to the general low relief of Makurdi, a large portion of the area is waterlogged and flooded during heavy rainstorm (Ologunorisa \& Tersoo, 2006). This provide suitable environment for snails to breed. Natural pasture is available in Makurdi throughout the year. Cattle rearing in Nigeria is predominantly nomadic system, where Fulani herdsmen travel on foot for very long distances for grazing purpose (Blench, 1999). During the dry season, Fulani herdsmen from the extreme north eastern states and north western states travel over a thousand kilometres to Benue valley where pasture is available throughout the year for grazing (Blench, 1999). Makurdi has two main abattoirs that supply slaughtered meat for over 1,000,000 people; an average of 80 heads of cattle are slaughtered daily (Ejeh et al., 2014a). Cattle slaughtered in Makurdi originate from Benue State and from cattle markets in surrounding states such as Nasarawa, Niger, Taraba, Adamawa, Bauchi, and Plateau State. Most of the cattle slaughtered in the abattoirs were adult local breeds (Ejeh et al., 2014b).

\section{Collection of data}

Five-year abattoir records (2008-2012) were collated from the Ministry of Agriculture and Natural Resources, Makurdi, Benue State. From these records, data on fasciolosis cases per month were extracted. These include the number of cattle examined before slaughter and the number of whole liver condemned as a result of the presence of Fasciola species. Partially condemned liver were not included in the study because their actual or estimated quantity was not recorded. It was also not possible to get the correct data on age, breed, and sex for each of the slaughtered cattle during the study period due to poor abattoir recording system at the Ministry of Agriculture and Natural Resources (MANR), Makurdi (Ejeh et al., 2014b). Veterinarians who are staff of the Ministry of Agriculture and Natural Resources (MANR), Makurdi, carried out the post-mortem examination.

Estimation of financial losses resulting from condemnation of liver due to fasciolosis

The average cost per kilogram of a liver was obtained through oral interviews with the butchers and meat traders at the abattoirs. The total numbers of whole livers that were condemned as unfit for human consumption during meat inspection were noted for cattle slaughtered in Makurdi abattoirs within the fiveyear period under review.

Financial losses in Naira and Dollar (US) were subsequently calculated based on a previous study and the formula: $\mathrm{DEL}=n \mathrm{w} \times \mathrm{Av} \cdot \mathrm{P} / \mathrm{kg}$ was used to determine financial losses (Ejeh et al., 2014b). Where DEL stands for direct economic losses due to total liver condemnation, $n$ is the total number of condemned liver for the period, $w$ is the average weight of a liver $(3.0 \mathrm{~kg}$ ) estimated from a pilot study, and Av. $\mathrm{P} / \mathrm{kg}$ is the average price per $\mathrm{kg}$ ( $\$ 1000=6.28$ USD) of whole non-condemned liver. US Dollar equivalent of Naira was calculated based on Central Bank of Nigeria's exchange rate which stood at N159.24 = 1 USD as at $31^{\text {st }}$ December, 2012 (CBN, 2015). 


\section{Data analysis}

From the data obtained, the annual, seasonal, monthly, and overall prevalence of fasciolosis were calculated as the total number of cases of fasciolosis detected divided by the total number of cattle slaughtered at particular points in time (Ejeh et al., 2014b). Data obtained were further subjected to ANOVA to establish levels of significance using SPSS $^{\circledR}$ version 16 statistical software.

\section{Results}

Annual and seasonal prevalence of bovine fasciolosis

Between 2008 and 2012, 64,978 cattle were slaughtered at Makurdi abattoirs in Benue State. Of these cattle, 9478 (14.59\%) were infected with Fasciola species.

Annual prevalence of bovine fasciolosis increased from $12.86 \%$ in 2008 to $21.21 \%$ in 2010 and then decreased to $10.90 \%$ in 2012 . There were significant differences $(P<0.05)$ between the prevalences of fasciolosis in 2010 and the rest of the years studied (Table 1 ).
During the late dry season, prevalence $(21.16 \%)$ of bovine fasciolosis was significantly higher $(P<0.05)$ compared to the other seasons of the year. The difference in prevalence of bovine fasciolosis from early wet season to early dry season was not significant (Table 1).

Direct economic losses (del) from liver condemnation due to fasciolosis

A total of 4220 livers were condemned during the study period, this amounted to $12,660 \mathrm{~kg}$ and valued at twelve million six hundred and sixty thousand (\$12.66 Million) naira equivalent to seventy nine thousand two hundred and fifty one US dollars and sixty cents (\$79251.60) (Table 2). The lowest direct economic losses ( $\$ 1,653,000$, \$10380.84) was recorded in 2011 and the highest losses $(\$ 3,966,000)$ were recorded in 2010 . There were significant differences between direct economic losses from liver condemnation due to bovine fasciolosis in Makurdi abattoirs from 2008 to 2012 (Table 2).

More livers were condemned (1594) during the early dry season than other periods with significantly $(P<0.05)$ high direct economic losses during the same (Table 2).

Table 1: Annual and seasonal prevalence of bovine fasciolosis lesions detected in cattle slaughtered at Makurdi abattoirs from 2008 to 2012

\begin{tabular}{lllll}
\hline Parameter & No. slaughtered & No. with Fasciola & Prevalence (\%) & $(95 \%$ C I) \\
\hline Year & & & & \\
2008 & 15642 & 2011 & $12.86^{\mathrm{b}}$ & $(9.12-17.43)$ \\
2009 & 14234 & 2177 & $15.29^{\mathrm{b}}$ & $(12.99-18.05)$ \\
2010 & 11943 & 2533 & $21.21^{\mathrm{a}}$ & $(15.83-28.30)$ \\
2011 & 11682 & 1502 & $12.86^{\mathrm{b}}$ & $(8.81-17.04)$ \\
2012 & 11476 & 1251 & $10.90^{\mathrm{b}}$ & $(7.86-13.76)$ \\
Season & & & & \\
Early wet & 16638 & 2162 & $12.99^{\mathrm{c}}$ & $(11.10-15.37)$ \\
Late & 16135 & 1904 & $11.80^{\mathrm{c}}$ & $(9.77-14.34)$ \\
Early dry & 15952 & 1960 & $12.29^{\mathrm{c}}$ & $(8.59-16.48)$ \\
Late dry & 16253 & 3439 & $21.16^{\mathrm{d}}$ & $(16.75-26.90)$ \\
Total & 64978 & 9478 & 14.59 & $(12.99-16.85$ \\
\hline
\end{tabular}

Mean percentages with the letters a and $d$ were different significantly $(P>0.05)$

Table 2: Direct economic loss from condemnation of livers as a result of detection of fasciolosis lesions detected in cattle slaughtered at Makurdi abattoirs

\begin{tabular}{lllll}
\hline Parameter & No. condemned $(\mathrm{n})$ & Wight, $W=\mathrm{nw}(\mathrm{kg})$ & \\
\hline Year & & & & $\$$ \\
2008 & 620 & 1860.00 & $1860000.00^{\mathrm{c}}$ & 11680.80 \\
2009 & 1015 & 3045.00 & $3045000.00^{\mathrm{d}}$ & 19122.60 \\
2010 & 1322 & 3966.00 & $3966000.00^{\mathrm{d}}$ & 24906.48 \\
2011 & 551 & 1653.00 & $1653000.00^{\mathrm{c}}$ & 10380.84 \\
2012 & 712 & 2136.00 & $2136000.00^{\mathrm{c}}$ & 13414.08 \\
Season & & & & \\
Early wet & 918 & 2754.00 & $2754000.00^{\mathrm{e}}$ & 17295.12 \\
Late wet & 740 & 2220.00 & $2220000.00^{\mathrm{e}}$ & 13941.60 \\
Early dry & 1594 & 4782.00 & $4782000.00^{\mathrm{f}}$ & 30030.96 \\
Late dry & 983 & 2904.00 & $2904000.00^{\mathrm{e}}$ & 18179.04 \\
Total & 4220 & 12660.00 & 12660000.00 & 79504.80 \\
\hline
\end{tabular}

Mean DEL with the different letter $d$ and $f$ were different significantly $(P>0.05) . W=$ Total average weight 


\section{Discussion}

Abattoirs are important in order to ensure wholesomeness of meat and meat products for human consumption. They also provide byproducts for livestock based industries. More importantly, abattoirs are used for the purpose of surveillance against animal and zoonotic diseases. Abattoir investigation of bovine fasciolosis have provided useful information on the prevalence and economic losses from condemnation of liver worldwide (Ekwunife \& Eneanya, 2006; Ibironke and Fasina, 2010; Bernardo et al., 2011; Abdulhakim \& Addis, 2012; Petros et al., 2013).

In this study we reported an overall prevalence of $14.56 \%$ (95\% C.I.: 12.99 - 16.85\%) bovine fasciolosis in cattle slaughtered at Makurdi abattoirs from 2008 to 2012. Similar results were reported from other parts of the country. Ekwunife \& Eneanya (2006) reported a prevalence of $10.5 \%$ in Onitsha while Raji et al. (2010) reported a prevalence of $13.09 \%$ in Zaria.

Lower prevalences of bovine fasciolosis were reported in the south eastern and south western parts of the country (Odigie \& Odigie, 2013; Oladele-Bukola \& Odetokun, 2014). OladeleBukola \& Odetokun (2014) explained that the rate of fasciolosis reported in the southern parts of the country was low because more animals, especially male with good body condition were transported to the south from the north since animals with good body condition are more resistant to infection and stress than animals with poor body condition.

There was no significant difference in the annual prevalence of bovine fasciolosis in cattle slaughtered in Makurdi abattoirs except in 2010 where the prevalence was significantly $(P>0.05)$ high. This may be as a result of increase in the intensity of meat inspection by veterinarians and not necessarily an increase in prevalence of the disease.

During the late dry season, the prevalence of bovine fasciolosis was high (21.16\%; 95\% C.I. 16.75 - 26.90\%), this represents a strong association between detection of Fasciola in cattle slaughtered in Makurdi abattoirs and season. This is in agreement with the results of Danwesh \& Ardo (2012) who also observed that the prevalence of fasciolosis was high before and during the onset of rainy season in Adamawa state, Nigeria. In other countries similar findings have been made (Benardo et al., 2011, Qureshi et al., 2012 and Shahzad et al., 2014). However, Njoku-Tony (2011) reported a high prevalence of bovine fasciolosis in cattle slaughtered in Imo state during the rainy season. Kuchai et al. (2011) also reported a low prevalence of bovine fasciolosis during the dry season among cattle of Ladakh in Egypt and further explained that it could be due to the existence of positive relationship between the prevalence of fasciolosis and rainfall, humidity and temperature.

Usually cattle acquire Fasciola at the onset of rainy season through ingestion of the infective stage (metacercariae) while grazing, when snail (Lymnea species) come out of their hibernation and release large numbers of metacercariae (Amato et al., 1986; Pfukenyi et al., 2006; Njoku-Tony et al., 2011; Ardo et al., 2013b; Shahzad et al., 2014). Similarly, Qureshi et al. (2012) observed that metacercariae can be found in considerable number on vegetation during rainy season and during the dry season along river banks, lakes, and streams. At this point, cattle come in contact with herbage infected with metacecarie. During the dry season, the concentration of snails increases along water bodies and thus leading to increased infection rate fasciola among cattle that graze along these areas.

Pathological lesions caused by bovine fasciolosis are the major cause of liver condemnation at Makurdi abattoirs, considering the amount $(12,660 \mathrm{~kg})$ of liver condemned from 2008 to 2012 and its financial implication. The direct economic losses (DEL) as a result of condemnation of liver due to detection of pathological lesions from bovine fasciolosis was estimated at twelve million six hundred and sixty thousand (\$12.66 million) naira, equivalent to seventy nine thousand two hundred and fifty one USD. In 2010 alone, the losses were approximately $\$ 3.966$ million $(\$ 24,906)$. Although this amount may not represent actual losses, it can be considered high for a lower middle income country like Nigeria (World Bank, 2015).

In a similar study, Ejeh et al. (2014b) reported a total direct economic losses of two million nine hundred and ten thousand naira $(\$ 2,910,000)$ from condemnation of edible organs as a result of detection of tubercle lesions in Makurdi abattoirs from 2008 to 2012. The differences between the direct economic losses from bovine tuberculosis and bovine fasciolosis in the same abattoirs and at the same period may further explain the results reported by Ibironke and Fasina (2010) that more livers were condemned as a result of fasciolosis than other diseases.

A total of $4782.00 \mathrm{~kg}$ of liver, valued at \#4,782,000) $(\$ 30,030.96)$ was condemned during the early dry season; this value was significantly $(P<0.05)$ high compared to other seasons. The reason for the differences might be as a result of the influence of season on the prevalence of bovine fasciolosis.

Economic losses reported in this study are relatively higher than those of previous studies in Nigeria viz. 191,300 in Maiduguri for a period of 
five years (Ahmed et al., 1994), \#1.4 million $(\$ 9,121)$ in Adamawa State (Ardo et al., 2013b) and $\$ 269,295$ (\$1683.09) in Port-Harcourt (Akpabio, 2014).

Economic losses from bovine fasciolosis have been reported in other parts of the world. In USA, Malone et al. (1982) reported a loss of $\$ 7.2$ million while $\$ 42.8$ million was reported in Switzerland by Schweizer et al. (2005) and $\$ 13,364.72$ in Central Ethiopia by Regassa et al. (2012). In a similar study performed in Turkey, Sariozkan and Yalcin (2011) reported that the estimated cost of fasciolosis for beef and dairy cows varied between $\$ 6.1-\$ 8.8$ and $\$ 28.9$ - \$42.6 million US\$ respectively. These figures are based on calculations from various factors such as production loss, cost of treatment, condemnation of livers, milk and meat losses. They however, reported smaller losses from liver condemnation compared to other factors.

We also observed that more livers were condemned during the early dry season. This may result from the fact that cattle may acquire the infective stage of Fasciola while grazing at river banks and around water bodies (Abdulhakim \& Addis, 2012) during the late dry season and development of lesion may occur during the early wet season and late wet season respectively. Therefore, at early dry season, gross pathological lesion may become more obvious with a corresponding increase in the number of livers condemned.

Bovine fasciolosis is an economic burden to farmers and butchers. These groups bear the

\section{References}

Abdulhakim Y \& Addis M (2012) An Abattoir Study on the prevalence of fasciolosis in cattle, sheep and goats in Debre Zeit Town, Ethiopia. Global Veterinaria, 8(3): 308314.

Abu O, Alumunku M \& Tsue PT (2011) Can smallscale tomato farmers flourish in Benue state, Nigeria? Journal of Agricultural Science, 2(2): 77- 82.

Ahmed MI, Nwosu CO \& Srivastava GC (1994). Economic importance of helminth disease of livestock in Maiduguri, Nigeria. Nigerian Journal of Animal Production, 21(1): 152-155.

Akpabio U. (2014). Incidence of bovine fasciolosis and its economic implications at transamadi abattoir Port-Harcourt, Nigeria. Acta Parasitologica Globalis, 5(3): 206209.

Amato SB, Rezende HEB, Gomes DC \&Serra-Freire NM (1986). Epidemiology of Fasciola hepatica in the Paraíba River Valley, São burden of direct economic losses alone since there is no compensation for condemned carcases or edible organs in Nigeria (Ibironke and Fasina, 2010; Ejeh et al., 2014b).

Bovine fasciolosis is endemic in cattle slaughtered in Makurdi abattoirs, with a significantly high prevalence during the late dry season.

Detection of gross pathology due to fasciolosis in cattle slaughtered at abattoirs in Makurdi accounts for huge financial losses from condemnation of livers which occur more during the early dry season.

Butchers were not compensated for condemnation of affected liver during meat inspection at Makurdi abattoirs.

Based on our results we recommend that compensations be reintroduced in order to encourage effective meat inspection and equitable sharing of losses.

Farmers should be educated through the state veterinary services on the need to strategically treat their animals with appropriate anthelmintic. Awareness should be created on the prevention and control of animal diseases especially, fasciolosis in the study area.

\section{Acknowledgement}

The authors are grateful to the staff of the Benue State Ministry of Agriculture and Natural Resources (MANR) for their support and cooperation during the course of this study.

Paulo. Brazilian Journal of Veterinary Parasitology, 22(3-4): 275-284.

Ardo MB, Aliyara Y H \& Lawal H (2013). Prevalence of bovine fasciolosis in major abattiors of Adamawa state, Nigeria. Bayero Journal of Pure and Applied Sciences, 6(1):12 - 16.

Ardo MB, Aliyara $\mathrm{YH}$, Lawal $\mathrm{H}$ \& Barkindo AA (2013). Economic assessment of bovine fasciolosis in some selected abattoirs of Adamawa state, Nigeria. International Journal of Livestock Research, 3(2) 1-8.

Arjona R, Riancho JA, Aguado JM, Salesa R \& González-Macías J (1995). Fascioliasis in developed countries: A review of classic and aberrant forms of the disease. Medicine (Baltimore). 74(1):13-23.

Bernardo CC, Carneiro MB, Avelar BR, Donatele DM, Martins IVF \& Pereira MJS (2011). Prevalence of liver condemnation due to bovine fasciolosis in Southern Espírito Santo: temporal distribution and 
economic losses. Revista Brasileira de Parasitologia Veterinaria, 20(1): 49-53.

Blench R (1999). Traditional Livestock Breeds: Geographical Distribution and Dynamics in Relation to the Ecology of West Africa, Overseas Development Institute, London, UK, 1999. Pp $167-188$.

Blench R (2010). Improving the lives of poor and excluded groups in the Nigerian meat and leather industry. Nigerian Meat and Leather Industries. Report for GEMS. Pp 1- 18.

CBN (2015). Monthly Exchange rates of Nigeria. www.cbnbank.org/rates/exrate.asp, retrieved on the 29-04-2015. 2015.

Damwesh SD \& Ardo MB (2012). Epidemiological studies of bovine fasciolosis in Yola modern abattoir, Adamawa state, Nigeria. Vom Journal of Veterinary Science, 9(1): $54-60$.

Ejeh EF, Adeshokan HK, Raji MA, Bello M, Musa JA, Kudi AC \& Cadmus SIB (2014a) Current status of bovine tuberculosis in Otukpo, Nigeria. Journal of Animal Production Advances, 4(8): 501-507.

Ejeh EF, Raji MA, Bello M, Lawan FA, Francis MI, Kudi AC \& Cadmus SIB (2014b). Prevalence and direct economic losses from bovine tuberculosis in Makurdi, Nigeria. Veterinary Medicine International, doi.org/10.1155/2014/904861.

Ekwunife CA \& Eneanya Cl (2006). Fasciola gigantica in Onitsha and environs. Animal Research International, 3(2): 448 - 450.

Gobo A E (1988). Relationship between rainfall trends and flooding in the Niger-Benue River Basin. The Journal of Meteorology, 13 (132): 318-324.

Ibironke AA \& Fasina FO (2010). Socio-economic implications of bovine liver rejection in a major abattoir in south western Nigeria. Revista de Ci^encias Agr'arias, 33(2) 211216.

Idoga S. \& Egbe OM (2012). Land use planning for vegetable farming in Benue State of Nigeria. Agriculture and Veterinary Sciences 12(6): $7-12$.

Khalid S, Desoukey AY, Elsiefy MA \& Elbahy NM (2010). An abattoir study on the prevalence of some gastrointestinal helminths of sheep in Gharbia Governorate, Egypt. Global Veterinaria, 5(2): 84-87.

Kuchai JA, Chishti MZ, Zaki MM, Dar Muzaffar Rasool SA, Ahmad J \& Tak H (2011). Some epidemiological aspects of fascioliasis among cattle of Ladakh. Global Veterinaria, 7(4): 342-346.

Malone JB, Loyacano A, Armstrong DA \& Archibald FL (1982). Fasciolosis: Economic impact and control in Gulf-Coast cattle based on seasonal transmission. Bovine Proceeding, 17(5): 126-133.

McKenna DR, Roebert DL, Bates PK, Schmidt TB, Hale DS, Griffin DB, Savell JW, Brooks JC, Morgan JB, Montgomery TH, Belk KE \& Smith GC (2002). National beef quality audit-2000: survey of targeted cattle and carcass characteristics related to quality, quantity, and value of fed steers and heifers. Journal of Animal Science 80 (5): 1212-1222.

Njoku-Tony, RF (2011). Bovine fascioliasis among slaughtered bovines in selected abattoirs in Imo state, Nigeria. World Rural Observations 3(1): $59-63$.

Odigie BE \& Odigie JO (2013). Fascioliasis in cattle: A survey of abattoirs in Egor, IkpobaOkha and Oredo Local Government Areas of Edo State, using histochemical techniques. International Journal of Basic, Applied and Innovative Research, 2(1): 1 9.

Okaiyeto SO, Salami OS, Danbirni SA, Allam L \& Onoja II (2012). Clinical, gross and histopathological changes associated with chronic fasciolosis infection in a dairy farm. Journal of Veterinary Advances, 2(8): 444-448.

Oladele-Bukola M \& Odetokun IO (2014). Prevalence of bovine fasciolosis at the Ibadan municipal abattoir, Nigeria. African Journal of Food, Agriculture, Nutrition and Development, 14(4): 90559070.

Ologunorisa TE \& Tersoo T (2006). The changing rainfall pattern and its implication for flood frequency in Makurdi, northern Nigeria. Journal of Applied Science and Environmental Management, 10(3): 97102.

Pan American Health Organization (2003). Zoonoses and Communicable Diseases Common to Man and animals. Scientific and Technical Publication No. 580 Pan American Health Organization, Pan American Sanitary Bureau, Regional Office of the World Health Organization 525 Twenty-third Street, N.W. Washington, D.C. 20037 USA. Pp 1- 408.

Petros A, Addisu Kebede, A \& Wolde A(2013). Prevalaence and economic significance of bovine fasciolosis in Nekemte municipal 
abattoir. Journal of Veterinary Medicine and Animal Health, 5(8): $202-205$.

Pfukenyi DM, Mukaratirwa S, Willingham AL \& Monard J (2006). Epidemiological studies of Fasciola gigantica infections in cattle in the highveld and lowveld communal grazing areas of Zimbabwe. Onderstepoort Journal of Veterinary Research, 73(3): 37-51.

Qureshi AW, Tanveer A, Maqbool A \& Niaz S (2012). Seasonal and monthly prevalence pattern of fascioliasis in buffaloes and its relation to some climatic factors in north eastern areas of Punjab, Pakistan. Iranian Journal of Veterinary Research, 13(2): 134-137.

Raji MA, Salami SO \& Ameh JA (2010). Pathological conditions and lesions observed in slaughtered cattle in Zaria abattoir. Journal of Clinical Pathology and Forensic Medicine, 1(2): $9-12$.

Regassa A, Woldemariam T, Demisie S, Moje N, Ayana D \& Abunna F (2012). Bovine fasciolosis: coprological, abattoir survey, and financial loss due to liver condemnation in Bsihoopin municipal abattoir, central Ethiopia. European Journal of Biological Science, 4(3) 83-90.

Sariozkan S \& Yalçın C. (2011). Estimating the total cost of bovine fasciolosis in Turkey.
Annals of Tropical Medical and

Parasitology. 105(6): 439-444.

Schweitzer G, Braun U, Deplazes P \& Torgerson PR (2005). Estimating the financial losses due to bovine fasciolosis in Switzerland. Veterinary Record, 157(7): 188-193.

Shahzad A, Iqbal Z, Ali M, Chaudhry $H R$, Sial N, Ahsan U, Ali A, \& Asif MZ (2014). Seasonal prevalence of Fasciola hepatica infection in buffaloes of Bahawalpur district of Punjab, Pakistan. Journal of Infection and Molecular Biology, 2(2): 30 32.

Soulsby EE (1982). Helminths, Arthropods and Protozoa of Domesticated Animals. Seventh edition, London, ELBS Bailliere Tindall and Cassel. Pp 787-792.

Steinfeld H (1997). Livestock and the environment -International Conference www.fao.org/wairdocs/lead/x6130e/x613 0e02.htm retrieved 23-02-2015.

World Bank Group (2015). Nigeria Overview Data. www.worldbank.org/en/country/nigeria, retrieved 25-05-2015.

Yahaya A \& Tyav YB (2014). A survey of gastrointestinal parasitic helminths of bovine slaughtered in abattoir, Wudil Local Government Area, Kano state, Nigeria. Greener Journal of Biological Sciences, 4(4): 128-134. 